Sains Malaysiana 50(10)(2021): 2993-3002

http://doi.org/10.17576/jsm-2021-5010-13

\title{
Assessment of Microbiological Safety and Physicochemical Changes of Grey Oyster Mushroom (Pleurotus sajor-caju) during Storage at $4{ }^{\circ} \mathrm{C}$ and $25^{\circ} \mathrm{C}$
}

(Penilaian Keselamatan Mikrobiologi dan Perubahan Fizikokimia Cendawan Tiram Kelabu (Pleurotus sajor-caju) semasa Penyimpanan pada suhu $4{ }^{\circ} \mathrm{C}$ dan $25^{\circ} \mathrm{C}$ )

\section{SUHAili, M.A.R. NOR-KhaizURA*, Z.A. NuR HANANI, M.R. ISMAIL-FITRY, N.I.P. SAMSUdIN \& N.N. JAMBARI}

\section{ABSTRACT}

This study aimed to evaluate the microbiological and physicochemical properties of grey oyster mushroom during storage (day $0,3,6,9,12)$ at $4{ }^{\circ} \mathrm{C}$ and $25^{\circ} \mathrm{C}$. The microbial quality and safety analyses were aerobic plate count (APC), yeast and mould count, Escherichia coli count, Bacillus cereus count, and Listeria monocytogenes count, while the physicochemical analyses were $\mathrm{pH}$, water activity, colour, and firmness. Grey oyster mushroom stored at $4{ }^{\circ} \mathrm{C}$ showed increasing trend in all microbial counts. A similar trend was observed at $25^{\circ} \mathrm{C}$, but with higher microbial counts except for L. monocytogenes which had a slight reduction from $1.82 \pm 1.16$ at day 0 to $0.24 \pm 0.34 \log$ CFU/g at day 6 . The pH of grey oyster mushroom was quite stable when stored at $4{ }^{\circ} \mathrm{C}(6.42 \pm 0.03$ at day 0 to $6.46 \pm 0.21$ at day 12$)$. A decrease in $\mathrm{pH}$ was observed when the mushroom was stored at $25^{\circ} \mathrm{C}(6.42 \pm 0.03$ at day 0 to $5.38 \pm 0.93$ at day 6$)$. The Browning Index (BI) increased which indicated by the colour changes on the mushroom cap (front and back) especially at $25^{\circ} \mathrm{C}$. Firmness analysis carried out on mushroom cap and stalk showed a decreasing trend during storage, at which $25{ }^{\circ} \mathrm{C}$ displayed prominent loss of firmness in cap and stalk as compared to $4^{\circ} \mathrm{C}$. In conclusion, slower deterioration was observed in grey oyster mushroom stored at $4{ }^{\circ} \mathrm{C}$ as compared to $25^{\circ} \mathrm{C}$. This is based on lower microbial counts, and minimal changes in $\mathrm{pH}, \mathrm{BI}$, and firmness of grey oyster mushroom.

Keywords: Ambient; grey oyster mushroom; microbiological changes; physicochemical changes; refrigeration; storage

\section{ABSTRAK}

Kajian ini bertujuan untuk menilai sifat mikrobiologi dan fizikokimia cendawan tiram kelabu semasa penyimpanan (hari 0, 3, 6, 9, 12) pada suhu $4{ }^{\circ} \mathrm{C}$ dan $25^{\circ} \mathrm{C}$. Analisis kualiti dan keselamatan mikrob yang dilakukan adalah kiraan plat aerobik (APC), kiraan yis dan kulat, kiraan Escherichia coli, kiraan Bacillus cereus dan kiraan Listeria monocytogenes. Sementara itu, analisis fizikokimia adalah pH, aktiviti air, warna dan keutuhan. Cendawan tiram kelabu yang disimpan pada suhu $4{ }^{\circ} \mathrm{C}$ menunjukkan trend peningkatan dalam semua kiraan mikrob. Trend yang serupa diperhatikan pada $25^{\circ} \mathrm{C}$, tetapi dengan kiraan mikrob yang lebih tinggi kecuali L. monocytogenes yang mengalami sedikit penurunan dari $1.82 \pm 1.16$ pada hari 0 hingga $0.24 \pm 0.34 \log$ CFU/g pada hari ke-6. pH cendawan tiram kelabu agak stabil apabila disimpan pada suhu $4{ }^{\circ} \mathrm{C}$ (6.42 \pm 0.03 pada hari ke-0 hingga $6.46 \pm 0.21$ pada hari ke-12). Penurunan pH diperhatikan ketika cendawan disimpan pada suhu $25{ }^{\circ} \mathrm{C}(6.42 \pm 0.03$ pada hari ke-0 hingga $5.38 \pm$ 0.93 pada hari ke-6). Indeks Keperangan (BI) meningkat seperti yang ditunjukkan oleh perubahan warna pada topi cendawan (depan dan belakang) terutama pada suhu $25^{\circ} \mathrm{C}$. Analisis keutuhan yang dilakukan pada topi dan tangkai cendawan menunjukkan trend menurun semasa penyimpanan dengan suhu $25^{\circ} \mathrm{C}$ menunjukkan kehilangan ketara dalam keutuhan topi dan tangkai berbanding pada suhu $4{ }^{\circ} \mathrm{C}$. Sebagai kesimpulan, kerosakan yang lebih perlahan diperhatikan dalam cendawan tiram kelabu yang disimpan pada suhu $4{ }^{\circ} \mathrm{C}$ berbanding suhu $25^{\circ} \mathrm{C}$. Ini ialah berdasarkan kiraan mikrob yang lebih rendah, serta perubahan minimum pada pH, BI dan keutuhan cendawan tiram kelabu.

Kata kunci: Cendawan tiram kelabu; penyejukan; penyimpanan; perubahan fizikokimia; perubahan mikrobiologi; suasana

\section{INTRODUCTION}

Grey oyster mushroom or scientifically known as Pleurotus sajor-caju is one of the 17 major mushroom varieties which can be grown in Malaysia (Mat Amin et al.
2013; Samsudin \& Abdullah 2019). Mushroom production value was around RM100 million in the year 2014, and the production value mainly comes from the cultivation of grey oyster mushroom which represents 90.89 per cent 
of the total cultivated mushroom in Malaysia (Rosmiza et al. 2016). Grey oyster mushroom is being cultivated and commercialised in the lowlands of Malaysia (Amin \& Harun 2015) due to the favourable tropical climatic conditions. Its cultivation is relatively simple with low production costs, thus leading it to being available all year-round. Due to its unique taste (Ang \& Ismail-Fitry), this mushroom is high in consumption and demand among Malaysians. Generally, mushrooms have high amount of proteins, essential amino acids, carbohydrates, minerals, vitamins, and low calorie (Wakchaure 2011). Most edible mushrooms are known to contain protein value of 14 to 19 per cent based on dry weight, which is relatively higher than the protein contents of vegetables; thus, they could be a promising alternative to meat (Alexander 2013; Amuneke et al. 2011; Bashir et al. 2014; Jonathan et al. 2012; Rosmiza et al. 2016).

Despite all the nutritional advantages, fresh mushrooms have a short shelf life of three to four days at room/ambient temperature. The short shelf life is due to the absence of cuticle to protect them from both physical damage and microbial attack, as well as having high respiration rate and (Villaescusa \& Gil 2003). Due to these factors, mushrooms cannot be completely sealed in a pack as they will decay due to the reaction of browning, wilting, liquefaction, texture loss, aroma loss, and flavour loss (Kamal et al. 2015). The decay might also arise from bacterial contamination on the tissues of the mushrooms. In contrast, browning might be caused by a synergistic combination of microbial and auto-enzymatic reaction on the tissues of the mushrooms (Kamal et al. 2015).

A study on fresh oyster mushroom contamination in Dhaka, Bangladesh found that some of the mushrooms contained coliform, faecal coliform, E. coli, and Salmonella spp. with the highest count reported on standard plate count was $8.9 \mathrm{log}$ CFU/g (Mustafa Kamal et al. 2010). Kim et al. (2016) observed that shiitake mushrooms cultivated in Virginia, USA had aerobic mesophilic count of $7.5 \pm 1.1 \log \mathrm{CFU} / \mathrm{g}$, yeast and mould count of $6.0 \pm 0.3 \mathrm{log} \mathrm{CFU} / \mathrm{g}$, coliform count of $1.9 \pm 1.1 \log \mathrm{MPN} / \mathrm{g}$, and were also detected with Listeria spp. Fresh grey oyster mushroom could contain spoilage and pathogenic microorganisms due to crosscontamination from its growth substrate, and during postharvest handling. Furthermore, keeping the grey oyster mushroom at different temperatures could provide various microbial profiles and physicochemical changes. Therefore, the objective of this study was to evaluate the microbiological quality and safety, and physicochemical properties of grey oyster mushroom during storage at refrigeration $\left(4^{\circ} \mathrm{C}\right)$ and ambient $\left(25^{\circ} \mathrm{C}\right)$ temperatures.

\section{MATERIALS AND Methods}

\section{SAMPLE COLLECTION AND EXPERIMENTAL DESIGN}

Fresh grey oyster mushroom was purchased from the Mushroom Unit, Crop Division, University Agriculture Park (UAP), Universiti Putra Malaysia (UPM), Serdang, Selangor, Malaysia on the day it was harvested. The samples were packed in a clear polypropylene bag, and heat-sealed. The packaged mushrooms were brought to the laboratory in a cold box, and immediately kept at 4 ${ }^{\circ} \mathrm{C}$ and $25{ }^{\circ} \mathrm{C}$ for 12 days. The samples were analysed for microbiological and physicochemical properties at three-day intervals during storage (day $0,3,6,9,12$ ). The experiments were carried out in triplicates.

\section{MICROBIOLOGICAL ANALYSES}

Sample of grey oyster mushroom was aseptically weighed for $50 \mathrm{~g}$, and diluted with $450 \mathrm{~mL}$ of sterile peptone water diluent before being homogenised for 2 min. This yielded a $10^{-1}$ dilution. Then, $1 \mathrm{~mL}$ of the dilution was serially diluted into $9 \mathrm{~mL}$ of similar diluent until $10^{-6}$. All dilution factors $\left(10^{-1}\right.$ to $\left.10^{-6}\right)$ were vortexed. Next, 100 $\mu \mathrm{L}$ from each dilution factor was spread onto plate count agar (PCA) (Oxoid, Hampshire, UK) for aerobic plate count, potato dextrose agar (PDA) (Oxoid, Hampshire, UK) for yeast and mould count, eosin methylene blue (EMB) for E. coli count, Bacillus agar (Oxoid, Hampshire, UK) for $B$. cereus count, and PALCAM agar with PALCAM Selective Supplement (SR0150) (Oxoid, Hampshire, UK) for L. monocytogenes count. Inoculated agar plates were incubated at $37^{\circ} \mathrm{C}$ for $48 \mathrm{~h}$. For selective agar, colonies were enumerated based on the following characteristics; for $E$. coli, purple-coloured colonies with green metallic sheen; for L. monocytogenes, dimpled brown/black coloured colonies with black halo; and for B. cereus, peacock blue colonies with precipitate and peacock blue medium were observed. Microbial growth was reported as logarithm numbers of colony-forming unit per gram $\left(\log _{10} \mathrm{CFU} / \mathrm{g}\right)$ of samples.

\section{pH AND WATER ACTIVITY ANALYSES}

$\mathrm{pH}$ analysis was carried out by diluting $50 \mathrm{~g}$ of sample into $450 \mathrm{~mL}$ of peptone water diluent. Peptone water is known to have a $\mathrm{pH}$ of $7.2 \pm 0.2$ (Thermo Scientific 2017). The $\mathrm{pH}$ meter was calibrated with buffers of $\mathrm{pH} 4.01,9.21$, and 7.00 (Mettler Toledo, USA), and the measurements of $\mathrm{pH}$ were carried out.

Water activity analysis was carried out using AquaLab Series 3 Water Activity Analyzer (Decagon Devices, USA). A small portion, approximately $5 \mathrm{~g}$ of the 
sample, was placed onto the measuring container before being loaded into the measuring chamber, and sealed for the measurement.

\section{COLOUR ANALYSIS}

The colour analysis of the grey oyster mushroom as a function of storage time was carried out using a handheld colorimeter (Konica Minolta CR-410, Japan). The instrument was first calibrated against a white calibration plate prior to colour measurement. The colour measurement of the samples was carried out by placing measuring head flat on the front and back caps of the grey oyster mushroom. On the other hand, the browning index (BI) of the grey oyster mushroom as a function of storage time was calculated according to $L^{*}$ (light to dark), $a^{*}$ (red to green), and $b^{*}$ (yellow to blue) using the following formula (Kortei et al. 2015):

Browning Index $($ B.I $)=[100(\mathrm{x}-0.31)] / 0.17$

where; $\mathrm{x}=\left(a^{*}+1.75 L^{*}\right) /\left(5.645 L^{*}+a^{*}-3.012 b^{*}\right)$

\section{FIRMNESS ANALYSIS}

A TA.XT2i Texture Analyser (Stable Micro Systems, UK) was used to measure the firmness properties of grey oyster mushroom. Penetration evaluation was carried out using a cylindrical probe with a diameter of $2 \mathrm{~mm}$, and penetration of mushroom cap and stalk at depth of 10 and $15 \mathrm{~mm}$, respectively, with pre-test, test and post-test speed of $5.0 \mathrm{~mm} / \mathrm{s}$ (Lagnika et al. 2013).

\section{STATISTICAL ANALYSIS}

All experiments were done in triplicate, and results were expressed as mean \pm SD (standard deviation). Statistical analyses were carried out using Minitab 19 (Minitab Inc., State College, PA, USA). One-Way Analysis of variance (ANOVA) with Tukey multiple comparison test were applied to find out the significant differences within the means of each microbial populations, and the means of each physicochemical properties between storage time (days). Significant difference was taken at $p<0.05$.

\section{RESULTS AND DISCUSSION}

\section{AEROBIC PLATE COUNT (APC) AND YEAST AND MOULD COUNT (YMC) IN GREY OYSTER MUSHROOM}

Aerobic plate count (APC) indicates the level of viable aerobic bacteria in a product. The APC of grey oyster mushroom during storage at 4 and $25^{\circ} \mathrm{C}$ is presented in Table 1 which shows that it increased with storage time from day 0 to day 12 for both storage temperatures. Grey oyster mushroom stored at $4{ }^{\circ} \mathrm{C}$ had a significant increase $(p<0.05)$ in APC on day 3, up to $7.45 \log \mathrm{CFU} / \mathrm{g}$ from the initial APC of $3.87 \log$ CFU/g. However, the APC for day 6 , 9 and 12 significantly decreased to an average of $4.00 \mathrm{log}$ $\mathrm{CFU} / \mathrm{g}$. The fluctuation in APC could be due to the effect of mushroom respiration in which it takes up oxygen and produces carbon dioxide (Iqbal et al. 2009). In a microenvironment (i.e. in food packaging) that contains less oxygen than normal air, spoilage is slowed down. It has been reported that another species of oyster mushroom (P. ostreatus) packed in low-density polyethylene plastic also showed fluctuation in the percentage of $\mathrm{O}_{2}$ and $\mathrm{CO}_{2}$ contents following storage at $4{ }^{\circ} \mathrm{C}$ for 11 days (Sapata et al. 2009).

Contradicting trend was observed when grey oyster mushroom was stored at $25^{\circ} \mathrm{C}$, during which the APC steadily increased over the 12 days of storage. The APC was enumerated until day 6 with $7.10 \log \mathrm{CFU} / \mathrm{g}$, and grey oyster mushroom was considered spoiled due to mould growth and fishy smell detected on day 9 and 12 . Therefore, all analyses for samples at $25{ }^{\circ} \mathrm{C}$ could only be carried out until day 6. Mesophilic microorganisms can survive at temperatures between $10{ }^{\circ} \mathrm{C}$ and $50{ }^{\circ} \mathrm{C}$ with an optimum of around $20^{\circ} \mathrm{C}$ to $37^{\circ} \mathrm{C}$. This group of mesophiles is also known to cause rot and fermentation which are major manifestations of food spoilage (Jay et al. 2008). In a previous study, Venturini et al. (2011) found that the microbial count of mesophilic microorganisms detected in another species of oyster mushroom $(P$. ostreatus) was $5.30 \pm 0.6 \log \mathrm{CFU} / \mathrm{g}$ at day 0 . The count reported was slightly higher than the count in the current study; this could be due to the samples purchased from retail markets across Zaragoza, Spain, and no temperature storage was controlled.

Table 1 also shows the yeast and mould count at $4{ }^{\circ} \mathrm{C}$ and $25^{\circ} \mathrm{C}$. There was also an increasing trend throughout the storage at both storage temperatures; rather similar to APC. Yeasts and moulds have the ability to grow under broad temperature range $\left(10{ }^{\circ} \mathrm{C}\right.$ to $\left.35^{\circ} \mathrm{C}\right)$, with a few species capable of growth below or above this range. Both yeasts and moulds cause various degrees of deterioration and decomposition of foods. They can invade and colonise any type of food at any time throughout the supply chain; they invade crops such as grains, nuts, beans, and fruits in fields before harvesting and during storage (Hitchins et al. 1998). 
TABLE 1 . Total plate count and yeast and mould count in grey oyster mushroom during storage at $4{ }^{\circ} \mathrm{C}$ and $25{ }^{\circ} \mathrm{C}$

\begin{tabular}{ccccc}
\hline & \multicolumn{3}{c}{$4{ }^{\circ} \mathrm{C}$} & $2{ }^{\circ} \mathrm{C}$ \\
\cline { 2 - 5 } Days & $\begin{array}{c}\text { Total plate count } \\
(\text { Log CFU/g) }\end{array}$ & $\begin{array}{c}\text { Yeast and mould count } \\
(\text { Log CFU/g) }\end{array}$ & $\begin{array}{c}\text { Total plate count } \\
(\text { Log CFU/g) }\end{array}$ & $\begin{array}{c}\text { Yeast and mould count } \\
(\text { Log CFU/g) }\end{array}$ \\
\hline 0 & $3.87 \pm 1.06^{\mathrm{B}}$ & $4.73 \pm 0.03^{\mathrm{C}}$ & $3.87 \pm 1.06^{\mathrm{B}}$ & $4.73 \pm 0.03^{\mathrm{B}}$ \\
3 & $7.45 \pm 0.00^{\mathrm{A}}$ & $7.37 \pm 0.00^{\mathrm{A}}$ & $5.02 \pm 1.69^{\mathrm{AB}}$ & $5.86 \pm 0.44^{\mathrm{A}}$ \\
6 & $4.96 \pm 0.23^{\mathrm{B}}$ & $5.73 \pm 0.13^{\mathrm{B}}$ & $7.10 \pm 0.69^{\mathrm{A}}$ & $6.84 \pm 0.99^{\mathrm{A}}$ \\
9 & $4.34 \pm 0.18^{\mathrm{B}}$ & $5.13 \pm 0.86^{\mathrm{BC}}$ & n.a. & n.a. \\
12 & $4.12 \pm 0.68^{\mathrm{B}}$ & $5.30 \pm 0.67^{\mathrm{BC}}$ & n.a. & n.a. \\
\hline
\end{tabular}

Data are mean $\pm \mathrm{SD}$ of triplicate $(n=3)$. Means within a column that do not share similar letter are significantly different $(p<0.05)$. n.a.: data not available due to sample spoilage during storage.

\section{Escherichia coli COUNT IN GREY OYSTER MUSHROOM}

Escherichia coli is a rod-shaped Gram-negative bacterium, and an indicator microorganism that reflects poor level of hygiene and sanitation of food processing. $E$. coli count in the grey oyster mushroom is presented in Table 2. The initial count of $E$. coli at both temperatures was $3.37 \pm 0.18 \log \mathrm{CFU} / \mathrm{g}$. An increase in storage time led to an increase in E. coli count to $3.62 \pm 1.56 \mathrm{log}$ $\mathrm{CFU} / \mathrm{g}$ (on day 12 at $4{ }^{\circ} \mathrm{C}$ ) and $5.44 \pm 2.72 \mathrm{log} \mathrm{CFU} / \mathrm{g}$ (on day 6 at $25{ }^{\circ} \mathrm{C}$ ). Similar trend has been reported during the storage of $P$. ostreatus in various polymeric packaging in which the coliform count increased from 5.53 to $8.52 \log \mathrm{CFU} / \mathrm{g}$ from day 0 to day 11 , respectively (Sapata et al. 2009). Another study on fresh, processed, and preserved mushrooms varieties collected around Dhaka City found that $100 \mathrm{~g}$ oyster mushroom packed in polyethylene bags were positive for $E$. coli (Mustafa Kamal et al. 2010). Although E. coli does not thrive over a long period on plant surfaces, and is only associated with recent water contamination, to date, there is no regulation set on its presence on unprocessed fresh fruits and vegetables (Monaghan 2010).

TABLE 2. Escherichia coli count in grey oyster mushroom during storage at $4{ }^{\circ} \mathrm{C}$ and $25^{\circ} \mathrm{C}$

\begin{tabular}{ccc}
\hline & \multicolumn{3}{c}{$\begin{array}{c}\text { Escherichia coli count } \\
\text { (Log CFU/g) }\end{array}$} \\
\cline { 2 - 3 } Days & $4^{\circ} \mathrm{C}$ & $25^{\circ} \mathrm{C}$ \\
\hline 0 & $3.37 \pm 0.18^{\mathrm{B}}$ & $3.37 \pm 0.18^{\mathrm{A}}$ \\
6 & $3.57 \pm 0.42^{\mathrm{B}}$ & $5.74 \pm 2.47^{\mathrm{A}}$ \\
9 & $4.72 \pm 0.16^{\mathrm{A}}$ & $5.44 \pm 2.72^{\mathrm{A}}$ \\
12 & $2.34 \pm 3.30^{\mathrm{AB}}$ & n.a. \\
\hline
\end{tabular}

Data are mean \pm SD of triplicate $(n=3)$. Means within a column that do not share similar letter are significantly different $(p<0.05)$. n.a.: data not available due to sample spoilage during storage

PRESUMPTIVE Bacillus cereus AND Listeria monocytogenes COUNTS IN GREY OYSTER MUSHROOM

Bacillus cereus was detected in grey oyster mushroom at both storage temperatures (Table 3). Grey oyster mushroom stored at $4{ }^{\circ} \mathrm{C}$ showed an increase in presumptive $B$. cereus count from $0.50 \pm 0.71 \log \mathrm{CFU} / \mathrm{g}$ at day 0 to $1.67 \pm 2.37$ at day 12 . This trend was similar for sample stored at $25{ }^{\circ} \mathrm{C}$, where the count increased 
from $0.50 \pm 0.71$ (day 0) to $2.72 \pm 3.84 \log \mathrm{CFU} / \mathrm{g}$ (day 6). Bacillus cereus is readily available in the environment, including organic matter such as decaying vegetables, and also in the gut of invertebrates (Bottone 2010). Previously, B. cereus was detected in fresh whole and sliced shiitake mushroom, both at $1.0 \log \mathrm{CFU} / \mathrm{g}$ (Kim et al. 2016). The concern with B. cereus is the possibility of cereulide toxin production. Cereulide is often produced under favourable conditions such as in food with high starches, carbohydrates, vitamins, and trace minerals, and under physiological conditions such as neutral $\mathrm{pH}$, and intermediate to high water activity (Messelhausser et al. 2014).

Table 3 also presents the presumptive $L$. monocytogenes count in grey oyster mushroom. Grey oyster mushroom stored at $4{ }^{\circ} \mathrm{C}$ showed an increase in the presumptive L. monocytogenes count from $1.89 \pm$ $1.08 \log \mathrm{CFU} / \mathrm{g}$ at day 0 to $2.09 \pm 0.69 \mathrm{log} \mathrm{CFU} / \mathrm{g}$ at day 12. Nevertheless, there was a drop in the presumptive $L$. monocytogenes count at $25^{\circ} \mathrm{C}$ in which the initial value of $1.82 \pm 1.16 \log \mathrm{CFU} / \mathrm{g}$ decreased to $0.24 \pm 0.34 \mathrm{log}$
CFU/g at day 6. This could be due to the nature of this bacterium which grow at a temperature between -1.5 and $45^{\circ} \mathrm{C}$, and has tolerant towards acidic environment. However, at elevated temperature, this bacterium is more sensitive towards the acidic environment Food Standards Australia New Zealand (2013). This can be proven in Table 4, where the final $\mathrm{pH}$ of the sample at 4 and $25^{\circ} \mathrm{C}$ were $6.46 \pm 0.21$ and $5.38 \pm 0.93$, respectively. Based on a previous study on L. monocytogenes count in button mushroom, it was found that the amount of the bacterium increased to $\log 1$ and $\log 2$ at $4{ }^{\circ} \mathrm{C}$ and $10{ }^{\circ} \mathrm{C}$ storage within two days, respectively. After two days, the bacterial count remained constant until day 8 , after which a decline in the count to around 1 to $2 \log$ units reduction was observed due to the presence of competitive microflora (Gonzalez-Fandos et al. 2001). Additionally, according to LaBorde (2017), some of the substrates for mushroom compost/spawning is often derived from manure or manure-based component, which might harbour various pathogens. This could explain the presence of L. monocytogenes in this study.

TABLE 3. Presumptive Bacillus cereus and Listeria monocytogenes counts in grey oyster mushroom during storage at $4{ }^{\circ} \mathrm{C}$ and $25^{\circ} \mathrm{C}$

\begin{tabular}{|c|c|c|c|c|}
\hline \multirow{2}{*}{ Days } & \multicolumn{2}{|c|}{$4{ }^{\circ} \mathrm{C}$} & \multicolumn{2}{|c|}{$25^{\circ} \mathrm{C}$} \\
\hline & $\begin{array}{c}\text { B. cereus } \\
(\log \mathrm{CFU} / \mathrm{g})\end{array}$ & $\begin{array}{l}\text { L. monocytogenes } \\
(\mathrm{Log} \mathrm{CFU} / \mathrm{g})\end{array}$ & $\begin{array}{c}\text { B. cereus } \\
(\log \mathrm{CFU} / \mathrm{g})\end{array}$ & $\begin{array}{l}\text { L. monocytogenes } \\
\text { (Log } \mathrm{CFU} / \mathrm{g})\end{array}$ \\
\hline 0 & $0.50 \pm 0.71^{\mathrm{B}}$ & $1.89 \pm 1.08^{\mathrm{A}}$ & $0.50 \pm 0.71^{\mathrm{A}}$ & $1.82 \pm 1.16^{\mathrm{A}}$ \\
\hline 3 & $2.03 \pm 0.43^{\mathrm{A}}$ & $1.88 \pm 0.82^{\mathrm{A}}$ & $0.76 \pm 1.08^{\mathrm{A}}$ & $2.91 \pm 2.39^{\mathrm{A}}$ \\
\hline 6 & $1.84 \pm 2.61^{\mathrm{AB}}$ & $1.52 \pm 0.06^{\mathrm{A}}$ & $2.72 \pm 3.84^{\mathrm{A}}$ & $0.24 \pm 0.34^{\mathrm{B}}$ \\
\hline 9 & $2.37 \pm 3.35^{\mathrm{AB}}$ & $1.19 \pm 2.36^{\mathrm{A}}$ & n.a & n.a \\
\hline 12 & $1.67 \pm 2.37^{\mathrm{AB}}$ & $2.09 \pm 0.69^{\mathrm{A}}$ & n.a & n.a \\
\hline
\end{tabular}

Data are mean \pm SD of triplicate $(n=3)$. Means within a column that do not share similar letter are significantly different $(p<0.05)$. n.a.: data not available due to sample spoilage during storage

\section{pH AND WATER ACTIVITY OF GREY OYSTER MUSHROOM}

$\mathrm{pH}$ is a parameter that depicts the acidity/alkalinity of a product. The $\mathrm{pH}$ of grey oyster mushroom at $4{ }^{\circ} \mathrm{C}$ storage from day 0 to day 12 ranged from $\mathrm{pH} 6.30 \pm 0.17$ to 6.46 \pm 0.21 (Table 4). A research carried out by Roy et al. (2015) found that the $\mathrm{pH}$ value of fresh oyster mushroom (P. ostreatus) was $\mathrm{pH}$ 6.14. For grey oyster mushroom stored at $25^{\circ} \mathrm{C}$, the $\mathrm{pH}$ decreased from $\mathrm{pH} 6.42 \pm 0.03$ to $5.38 \pm 0.93$ from day 0 to day 6 of storage. This could be related to the breakdown of sugar to produce acids; at ambient temperature, this breakdown could be accelerated. Moreover, respiration occurs faster when storage temperature is high, which also leads to the production of acid (Wills et al. 1989). Low-temperature storage could be effective in slowing down the rate of respiration and senescence of fresh fruits and vegetables. 
The water activity of grey oyster mushroom was consistent $\left(0.98 \mathrm{a}_{\mathrm{w}}\right)$ throughout the storage at both $4{ }^{\circ} \mathrm{C}$ and $25^{\circ} \mathrm{C}$ (Table 4). According to Fernandez-Salguero et al. (1993), water activity above $0.95 \mathrm{a}_{\mathrm{w}}$ will cause bacteria to colonise the food, whereas, water activity below 0.95 $a_{w}$ will cause the yeasts and moulds to predominate. Most fresh fruits and vegetables has the water activity of 0.97 and above.

TABLE 4. $\mathrm{pH}$ and water activity of grey oyster mushroom during storage at $4{ }^{\circ} \mathrm{C}$ and $25{ }^{\circ} \mathrm{C}$

\begin{tabular}{ccccc}
\hline \multirow{2}{*}{ Days } & \multicolumn{2}{c}{$4{ }^{\circ} \mathrm{C}$} & \multicolumn{2}{c}{$25^{\circ} \mathrm{C}$} \\
\cline { 2 - 5 } & $6.42 \pm 0.03^{\mathrm{A}}$ & $0.98 \pm 0.01^{\mathrm{A}}$ & $6.42 \pm 0.03^{\mathrm{A}}$ & Water activity \\
\hline 0 & $6.30 \pm 0.17^{\mathrm{A}}$ & $0.98 \pm 0.00^{\mathrm{A}}$ & $5.91 \pm 0.71^{\mathrm{AB}}$ & $0.98 \pm 0.01^{\mathrm{A}}$ \\
3 & $6.37 \pm 0.01^{\mathrm{A}}$ & $0.98 \pm 0.00^{\mathrm{A}}$ & $5.38 \pm 0.93^{\mathrm{B}}$ & $0.98 \pm 0.00^{\mathrm{A}}$ \\
6 & $6.43 \pm 0.27^{\mathrm{A}}$ & $0.98 \pm 0.00^{\mathrm{A}}$ & n.a & n.a \\
9 & $6.46 \pm 0.21^{\mathrm{A}}$ & $0.98 \pm 0.00^{\mathrm{A}}$ & n.a & n.a \\
\hline
\end{tabular}

Data are mean $\pm \mathrm{SD}$ of triplicate $(n=3)$. Means within a column that do not share similar letter are significantly different $(p<0.05)$. n.a.: data not available due to sample spoilage during storage

COLOUR MEASUREMENT OF GREY OYSTER MUSHROOM Based on Table 5, the front cap of the grey oyster mushroom showed an increase in the browning index (BI) from day 0 (29.35) to day 12 (50.47) when stored at 4 ${ }^{\circ} \mathrm{C}$. Similar trend was also observed in the BI of the back cap at the same storage temperature. According to Xiao et al. (2011), suitable conditions in packaging permeability and product surface could prevent gas respiration which causes severe browning in mushrooms. Moreover, browning could also occur from microbial action and enzymatic reaction within the mushroom tissues (Kamal et al. 2015). Shock, cutting damage, and loss of firmness could activate browning of mushrooms, thus leading to adverse changes in their organoleptic and nutritional values (Toivonen \& Brummell 2008). For storage of grey oyster mushroom at $25^{\circ} \mathrm{C}$ (Table 6), the BI of front cap showed an increase from day 0 (40.58) to day $6(60.42)$. Back cap also showed an increase of BI from day 0 (24.34) to day 6 (43.09).

Tables 5 and 6 also show the $* L, * a$, and $* b$ values of mushroom caps (front and back) after 12 storage at 4 ${ }^{\circ} \mathrm{C}$ and $25^{\circ} \mathrm{C}$, respectively. According to Roshita et al. (2017), cap of fresh grey oyster mushroom had the ${ }^{*} L$, $* a$, and $* b$ values of $52.89 \pm 8.01,7.62 \pm 0.62$, and 10.57 \pm 1.94 , respectively. Almost similarly, Firdhaus et al. (2015) reported that fresh oyster mushroom showed the values of $59.70 \pm 3.01,8.54 \pm 0.36$, and $12.34 \pm 2.00$ for $* L$, $* a$ and $* b$ values, respectively. The difference between those studies and this study might be due to the effect of storage.

TABLE 5. CIE $L a b$ and Browning Index of grey oyster mushroom during storage at $4{ }^{\circ} \mathrm{C}$

\begin{tabular}{|c|c|c|c|c|c|c|c|c|}
\hline \multirow[t]{2}{*}{ Days } & \multicolumn{4}{|c|}{ Front Cap } & \multicolumn{4}{|c|}{ Back Cap } \\
\hline & $* L$ & $* a$ & $* b$ & $\begin{array}{l}\text { Browning } \\
\text { Index }\end{array}$ & $* L$ & $* a$ & $* b$ & $\begin{array}{l}\text { Browning } \\
\text { Index }\end{array}$ \\
\hline 0 & $\begin{array}{c}76.59 \pm \\
1.18^{\mathrm{A}}\end{array}$ & $\begin{array}{c}6.72 \pm \\
0.41^{\mathrm{ABC}}\end{array}$ & $\begin{array}{c}15.67 \pm \\
0.89^{\mathrm{B}}\end{array}$ & 29.35 & $\begin{array}{c}75.59 \pm \\
1.18^{\mathrm{A}}\end{array}$ & $\begin{array}{c}3.18 \pm \\
0.21^{\mathrm{A}}\end{array}$ & $\begin{array}{c}14.73 \pm \\
0.73^{\mathrm{C}}\end{array}$ & 24.34 \\
\hline 3 & $\begin{array}{c}77.92 \pm \\
1.61^{\mathrm{A}}\end{array}$ & $\begin{array}{c}6.34 \pm \\
0.70^{\mathrm{ABC}}\end{array}$ & $\begin{array}{c}17.08 \pm \\
1.24^{\mathrm{AB}}\end{array}$ & 30.29 & $\begin{array}{c}77.92 \pm \\
1.61^{\mathrm{A}}\end{array}$ & $\begin{array}{c}2.22 \pm \\
0.08^{\mathrm{B}}\end{array}$ & $\begin{array}{l}16.86 \pm \\
3.27^{\mathrm{ABC}}\end{array}$ & 25.96 \\
\hline 6 & $\begin{array}{c}70.09 \pm \\
9.08^{\mathrm{AB}}\end{array}$ & $\begin{array}{c}5.628 \pm \\
0.70^{\mathrm{C}}\end{array}$ & $\begin{array}{c}18.43 \pm \\
1.29^{\mathrm{AB}}\end{array}$ & 35.88 & $\begin{array}{c}75.52 \pm \\
1.40^{\mathrm{A}}\end{array}$ & $\begin{array}{c}3.44 \pm \\
0.49^{\mathrm{A}}\end{array}$ & $\begin{array}{c}20.47 \pm \\
2.38^{\mathrm{AB}}\end{array}$ & 34.34 \\
\hline 9 & $\begin{array}{c}62.58 \pm \\
0.00^{\mathrm{AB}}\end{array}$ & $\begin{array}{c}6.69 \pm \\
0.00^{\mathrm{B}}\end{array}$ & $\begin{array}{c}19.02 \pm \\
0.00^{\mathrm{AB}}\end{array}$ & 43.50 & $\begin{array}{c}76.83 \pm \\
0.00^{\mathrm{A}}\end{array}$ & $\begin{array}{c}3.10 \pm \\
0.00^{\mathrm{A}}\end{array}$ & $\begin{array}{c}20.62 \pm \\
0.00^{\mathrm{A}}\end{array}$ & 33.59 \\
\hline 12 & $\begin{array}{c}56.69 \pm \\
0.00^{\mathrm{B}}\end{array}$ & $\begin{array}{c}7.04 \pm \\
0.00^{\mathrm{A}}\end{array}$ & $\begin{array}{c}19.46 \pm \\
0.00^{\mathrm{A}}\end{array}$ & 50.47 & $\begin{array}{c}71.35 \pm \\
0.00^{\mathrm{B}}\end{array}$ & $\begin{array}{c}3.16 \pm \\
0.00^{\mathrm{A}}\end{array}$ & $\begin{array}{c}19.16 \pm \\
0.00^{\mathrm{B}}\end{array}$ & 33.92 \\
\hline
\end{tabular}

Data are mean $\pm \mathrm{SD}$ of triplicate $(n=3)$. Means within a column that do not share similar letter are significantly different $(p<0.05)$ 
TABLE 6. CIE Lab and Browning Index of grey oyster mushroom during storage at $25^{\circ} \mathrm{C}$

\begin{tabular}{|c|c|c|c|c|c|c|c|c|}
\hline \multirow[t]{2}{*}{ Days } & \multicolumn{4}{|c|}{ Front Cap } & \multicolumn{4}{|c|}{ Back Cap } \\
\hline & $* L$ & $* a$ & $* b$ & $\begin{array}{l}\text { Browning } \\
\text { Index }\end{array}$ & $* L$ & $* a$ & $* b$ & $\begin{array}{l}\text { Browning } \\
\text { Index }\end{array}$ \\
\hline 0 & $\begin{array}{c}76.59 \pm \\
1.18^{\mathrm{A}}\end{array}$ & $\begin{array}{c}6.72 \pm \\
0.41^{\mathrm{A}}\end{array}$ & $\begin{array}{c}15.67 \pm \\
0.89^{\mathrm{B}}\end{array}$ & 29.35 & $\begin{array}{c}75.59 \pm \\
1.18^{\mathrm{A}}\end{array}$ & $\begin{array}{c}3.18 \pm \\
0.21^{\mathrm{A}}\end{array}$ & $\begin{array}{c}14.73 \pm \\
0.73^{\mathrm{C}}\end{array}$ & 24.34 \\
\hline 3 & $\begin{array}{c}60.30 \pm \\
2.17^{\mathrm{B}}\end{array}$ & $\begin{array}{c}5.94 \pm \\
0.51^{\mathrm{A}}\end{array}$ & $\begin{array}{c}21.08 \pm \\
0.93^{\mathrm{A}}\end{array}$ & 49.54 & $\begin{array}{c}72.28 \pm \\
1.03^{\mathrm{B}}\end{array}$ & $\begin{array}{c}2.76 \pm \\
0.04^{\mathrm{B}}\end{array}$ & $\begin{array}{c}18.15 \pm \\
0.50^{\mathrm{B}}\end{array}$ & 31.15 \\
\hline 6 & $\begin{array}{c}49.61 \pm \\
1.08^{\mathrm{C}}\end{array}$ & $\begin{array}{c}6.63 \pm \\
0.37^{\mathrm{A}}\end{array}$ & $\begin{array}{c}20.00 \pm \\
0.89^{\mathrm{A}}\end{array}$ & 60.42 & $\begin{array}{c}63.22 \pm \\
5.64^{\mathrm{C}}\end{array}$ & $\begin{array}{c}2.03 \pm \\
0.00^{\mathrm{C}}\end{array}$ & $\begin{array}{c}21.56 \pm \\
1.83^{\mathrm{A}}\end{array}$ & 43.09 \\
\hline
\end{tabular}

Data are mean \pm SD of triplicate $(n=3)$. Means within a column that do not share similar letter are significantly different $(p<0.05)$

\section{FIRMNESS PROFILE OF GREY OYSTER MUSHROOM}

Texture analysis of grey oyster mushroom was carried out on the cap and the stalk to measure its firmness. It was found that the firmness of the cap and stalk significantly decreased throughout the storage (Figure 1). A study conducted by Lagnika et al. (2013) on the shelf life of white mushroom (Agaricus bisporus) with the treatment of ultrasound and high-pressure argon found that all the treated and control samples showed a reduction in firmness (N) after nine days of storage at $4{ }^{\circ} \mathrm{C}$, as observed in this study. At $25^{\circ} \mathrm{C}$, the firmness of the grey oyster mushroom cap and stalk exhibited similar decreasing trend (cap: 1.86 to $0.95 \mathrm{~N}$; stalk: 5.71 to $3.66 \mathrm{~N}$; Figure 2) to that observed at $4{ }^{\circ} \mathrm{C}$. According to Firdhaus et al. (2015), fresh grey oyster mushroom treated with different sound intensities had the firmness of between $117.31 \pm 43.93 \mathrm{~g}$ and $107.24 \pm 59.60 \mathrm{~g}$. In this study, higher firmness of fresh (day 0) grey oyster mushroom cap was observed $(1.86 \pm 0.17 \mathrm{~N}$ or $189.85 \pm 17.32 \mathrm{~g})$.
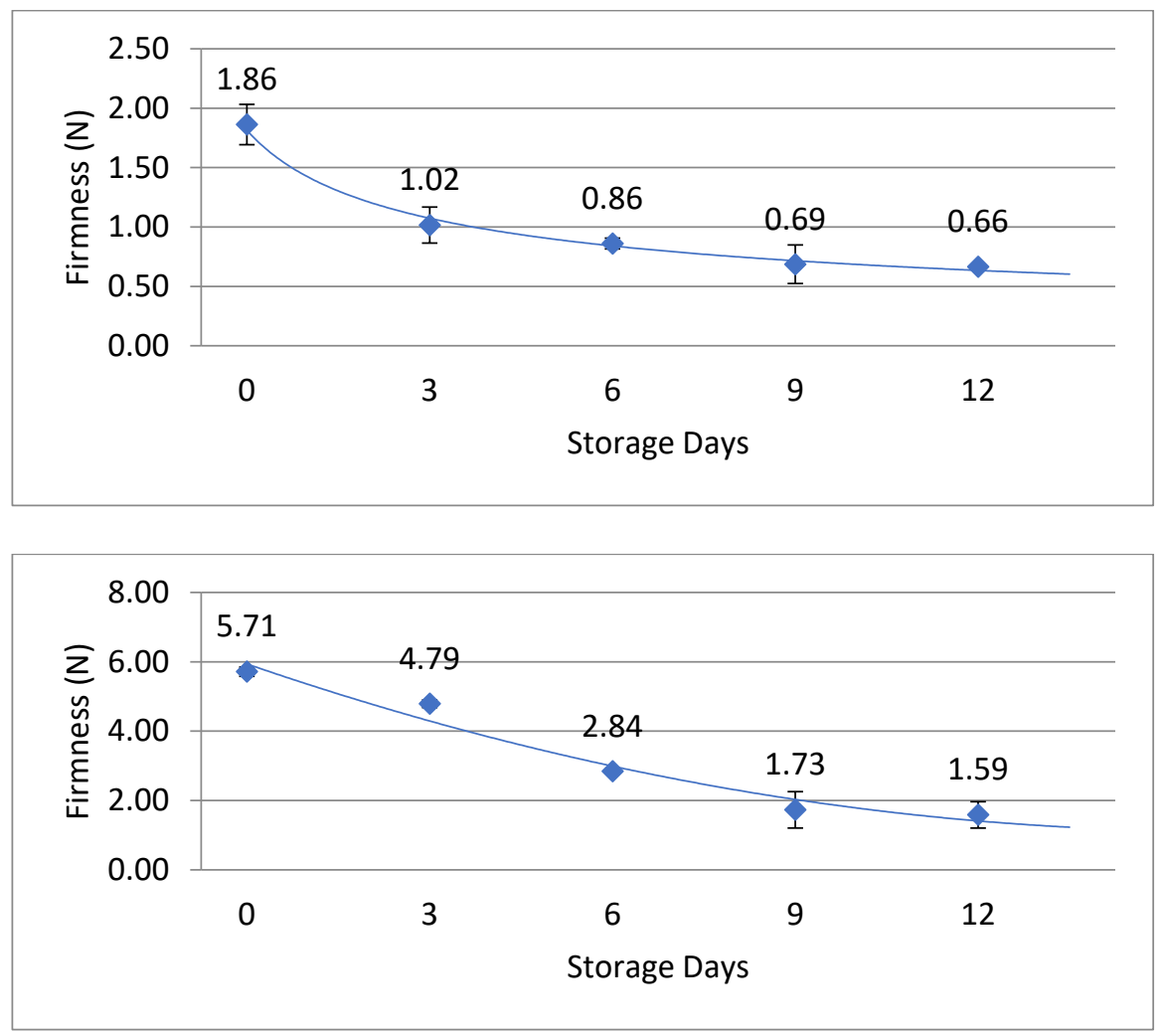

FIGURE 1. Firmness of grey oyster mushroom cap (a) and stalk (b) during storage at $4{ }^{\circ} \mathrm{C}$ 

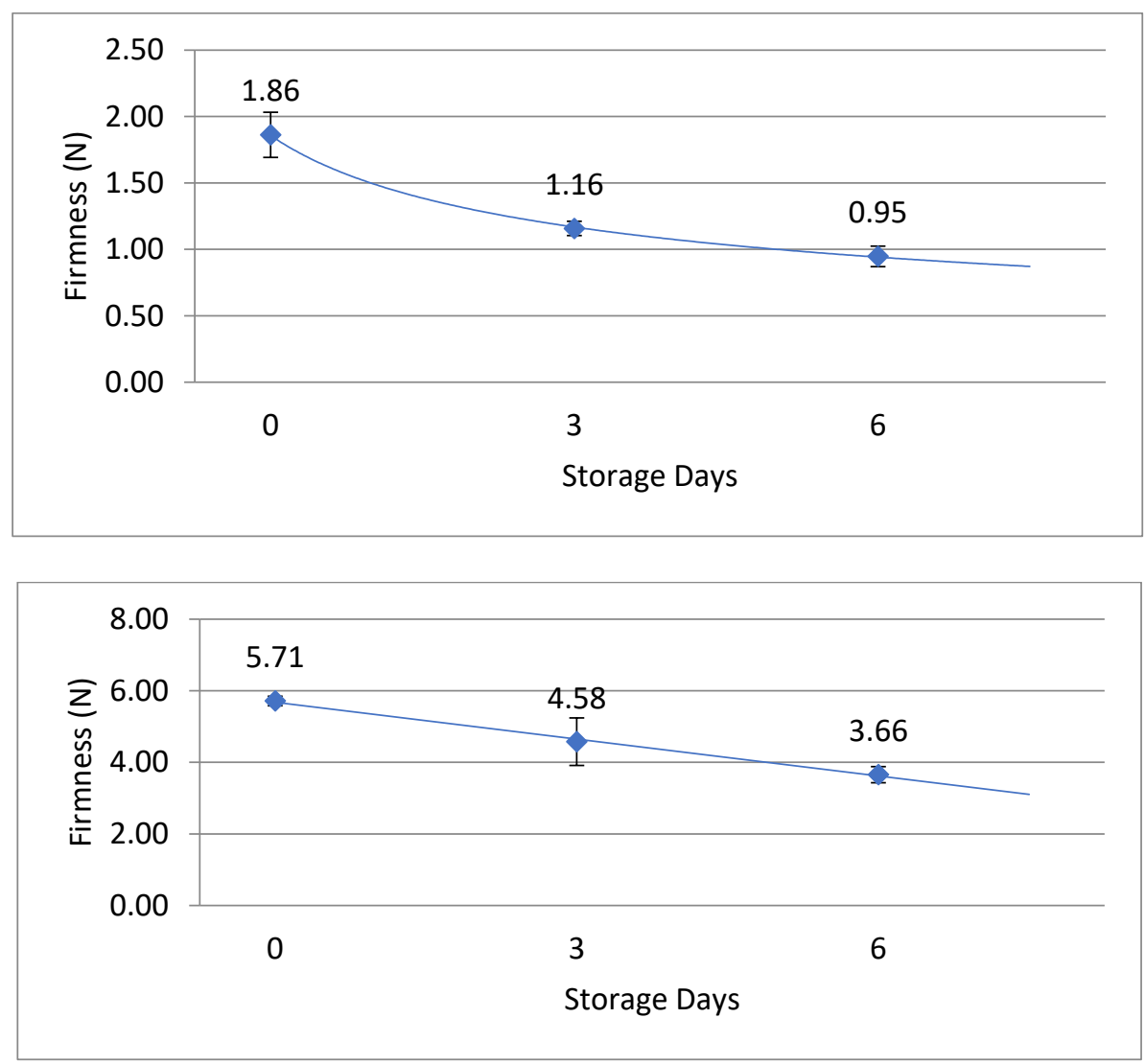

FIGURE 2. Firmness of grey oyster mushroom cap (a) and stalk (b) during storage at $25^{\circ} \mathrm{C}$

\section{CONCLUSION}

This study analysed the effect of storage temperatures (refrigeration, $4{ }^{\circ} \mathrm{C}$; ambient, $25^{\circ} \mathrm{C}$ ) on the microbiological quality and safety, and physicochemical properties of grey oyster mushroom. Lower temperature $\left(4{ }^{\circ} \mathrm{C}\right)$ was found able to delay unfavourable changes in the microbial counts where the values of total plate count and yeast and mould count exceeded log $6.00 \mathrm{CFU} / \mathrm{g}$ only on day 6 , as compared to storage at $25^{\circ} \mathrm{C}$. For physicochemical changes, grey oyster mushroom showed less adverse changes when stored at $4{ }^{\circ} \mathrm{C}$ as compared to $25^{\circ} \mathrm{C}$; lower browning index (BI), and minimal $\mathrm{pH}$ and firmness reduction were observed. The water activity of grey oyster mushroom remained constant during storage at both temperatures. Therefore, storage and retail of grey oyster mushroom at lower temperature $\left(4^{\circ} \mathrm{C}\right)$ is recommended.

\section{REFERENCES}

Alexander, S. 2013. How to Grow your Own Oyster Mushrooms on Straw. The Premature Research Institute.
Amin, M.Z. \& Harun, A. 2015. Competitiveness of the Mushroom Industry in Malaysia. Food and Fertilizer Technology Center for the Asian and Pacific Region http://ap.fftc.agnet. org/ap_db.php?id=481\&print=1. Accessed on 31 January, 2016.

Ang, S.S. \& Ismail-Fitry, M.R. 2019. Production of different mushroom protein hydrolysates as potential flavourings in chicken soup using stem bromelain hydrolysis. Food Technology and Biotechnology 57(4): 472-480.

Bashir, A., Vaida, N. \& Ahmad Dar, M. 2014. Medicinal importance of mushroom: A review. International Journal of Advanced Research 2: 1-4.

Bottone, E.J. 2010. Bacillus cereus, a volatile human pathogen. Clinical Microbiology Reviews 23(2): 382-398.

Fernandez-Salguero, J., Gomez, R. \& Carmona, M.A. 1993. Water activity in selected high-moisture foods. Journal of Food Composition and Analysis 6: 364-369.

Firdhaus, S.M., Shamsul Bahri, A.R., Rajihan, M., Rahman, A.A., Rohana, M.Z. \& Ibrahim, R. 2015. Growth performance and postharvest quality of grey oyster mushroom (Pleurotus sajor $c a j u)$ subjected to different sound intensity treatments prior to fruiting body formation. Advances in Life Science and Technology 28: 51-59. 
Food Standards Australia New Zealand. 2013. Listeria monocytogenes. Food Standards Australia New Zealand. https://www.foodstandards.gov.au/publications/Documents/ Listeria\%20monocytogenes.pdf. Accessed on 20 June, 2017.

Gonzalez-Fandos, E., Olarte, C., Gimenez, M., Sanz, S. \& Simon, S. 2001. Behaviour of Listeria monocytogenes in packaged fresh mushrooms (Agaricus bisporus). Journal of Applied Microbiology 91: 795-805.

Hitchins, A.D., Jinneman, K. \& Chen, Y. 1998. Bacteriological Analytical Manual. Washington, DC: Food and Drug Administration.

Iqbal, T., Rodrigues, F.A.S., Mahajan, P.V. \& Kerry, J.P. 2009. Effect of time, temperature, and slicing on respiration rate of mushrooms. Journal of Food Science 74(6): E298-E303.

Jay, J.M., Loessner, M.J. \& Golden, D.A. 2008. Modern Food Microbiology. New York: Springer Science \& Business Media.

Jonathan, S.G., Okorie, A.N., Babayemi, O.J. \& Akinfemi, A. 2012. Biodegradation of agricultural wastes (rice straw and sorghum stalk) into substrates of utilizable products using white rot fungus (Pleurotus florida). Nature and Science 10: 131-134

Kamal, A.M., Khair, A., Begum, F., Chowdury, K. \& Karim, R. 2015. Effect of respiratory gases $\left(\mathrm{O}_{2} ; \mathrm{CO}_{2}\right)$ on shelf life of fresh oyster mushroom packaged with different sealable polymeric materials. Bangladesh Journal of Scientific and Industrial Research 50(3): 205-210.

Kim, C., Nartea, T.J., Pao, S., Li, H., Jordan, K.L., Xu, Y.X., Stein, R.A. \& Sismour, E.N. 2016. Evaluation of microbial loads on dried and fresh shiitake mushrooms (Lentinula edodes) as obtained from internet and local retail markets, respectively. Food Safety 4(2): 45-51.

Kortei, N.K., Odamtten, G.T., Obodai, M., Appiah, V. \& Akonor, P.T. 2015. Determination of color parameters of gamma irradiated fresh and dried mushrooms during storage. Croatian Journal of Food Technology, Biotechnology and Nutrition 10(1-2): 66-71.

LaBorde, L. 2017. Control of Listeria monocytogenes in Mushroom Growing and Packing Environments. http:// extension.psu.edu/food/safety/farm/mushrooms/featuredsites/control-of-listeria-monocytogenes-in-mushroomgrowing-and-packing-environments.

Lagnika, C., Zhang, M., Nsor-Atindana, J. \& Tounkara, F. 2013. Extension of mushroom shelf-life by ultrasound treatment combined. International Agrophysics 28: 39-47.

Mat Amin, M.Z., Mohd, Y. \& Harun, A. 2013. Viability of oyster mushroom industry in Peninsular Malaysia. Economic and Technology Management Review 8: 13-25.

Messelhausser, U., Frenzel, E., Blochinger, C., Zucker, R., Kampf, P. \& Ehling-Schulz, M. 2014. Emetic Bacillus cereus are more volatile than thought: Recent foodborne outbreaks and prevalence studies in Bavaria (2007-2013). BioMed Research International 2014: Article ID. 465603.

Monaghan, J. 2010. Monitoring Microbial Food Safety of
Fresh Produce. https://www.food.gov.uk/sites/default/files/ multimedia/pdfs/microbial.pdf. Accessed on 2 June, 2017.

Mustafa Kamal, A.S., Begum, F. \& Khair, A. 2010. Assessment of microbiological quality of fresh-cut, processed and preserved mushrooms available in and around Dhaka City. Bangladesh Journal of Microbiology 27(2): 42-45.

Roshita, I., Ahmad Azmil Irfan, M.J., Sayed, M.Z.H., Adzemi, M.A. \& Zarina, Z. 2017. Enhancing growth and yield of grey oyster mushroom (Plearotus sajor caju) using different acoustic sound treatments. MATEC Web of Conferences 97: 01054. DOI: 10.1051/matecconf/20179701054.

Rosmiza, M.Z., Davies, W.P., Rosniza Aznie, C.R., Jabil, M.J. \& Mazdi, M. 2016. Prospects for increasing commercial mushroom production in Malaysia: Challenges and opportunities. Mediterranean Journal of Social Sciences 7: 406-415.

Roy, D.N., Azad, A.K., Sultana, F., Anisuzzaman, A.S. \& Khondkar, P. 2015. Nutritional profile and mineral composition of two edible mushroom varieties consumed and cultivated in Bangladesh. The Journal of Phytopharmacology 4(4): 217-220.

Samsudin, N.I.P. \& Abdullah, N. 2019. Edible mushrooms from Malaysia; A literature review on their nutritional and medicinal properties. International Food Research Journal 26: 11-31.

Sapata, M., Ramos, A., Ferreira, A., Andrada, L. \& Candeias, M. 2009. Quality maintenance improvement of Pleurotus ostreatus mushrooms by modified atmosphere packaging. Acta Scientiarum Polonorum Technologia Alimentaria 8(2): 53-60.

Thermo Scientific. 2017. Dehydrated Culture Media- Peptone Water. http://www.oxoid.com/UK/blue/prod_detail/ prod_detail.asp?pr $=\mathrm{CM} 0009 \& \mathrm{cat}=\& \mathrm{sec}=1$. Accessed on 29 May, 2017.

Toivonen, P.M. \& Brummell, D.A. 2008. Biochemical bases of appearance and texture changes in fresh-cut fruit and vegetables. Postharvest Biology and Technology 48(1): $1-14$.

Venturini, M.E., Reyes, J.E., Rivera, C.S., Oria, R. \& Blanco, D. 2011. Microbiological quality and safety of fresh cultivated and wild mushrooms commercialized in Spain. Food Microbiology 28(8): 1492-1498.

Villaescusa, R. \& Gil, M.I. 2003. Quality improvement of Pleurotus mushrooms by modified atmosphere packaging and moisture absorbers. Postharvest Biology and Biotechnology 28: 169-179.

Wakchaure, G.C. 2011. Postharvest handling of fresh mushrooms. In Mushrooms-Cultivation, Marketing and Consumption, edited by Singh, M., Vijay, B., Kamal, S. \& Wakchaure, G.C. India: Directorate of Mushroom Research. p. 197.

Wills, R.B., Mcglasson, W.B., Graham, D., Tlee, H. \& Hall, E.G. 1989. Postharvest-An Introduction to The Physiology and Handling of Fruit and Vegetables. 3rd ed. New York: Van Nostrand Reinhold. 
Xiao, G., Zhang, M., Shan, L., You, Y. \& Salokhe, V.M. 2011. Extension of the shelf-life of fresh oyster mushrooms (Pleurotus ostreatus) by modified atmosphere packaging with chemical treatments. African Journal of Biotechnology 10(46): 9509-9517.

M. Suhaili, M.A.R. Nor-Khaizura*, N.I.P. Samsudin \& N.N. Jambari

Department of Food Science

Faculty of Food Science and Technology

Universiti Putra Malaysia

43400 UPM Serdang, Selangor Darul Ehsan

Malaysia

Z.A. Nur Hanani \& M.R. Ismail-Fitry

Department of Food Technology

Faculty of Food Science and Technology

Universiti Putra Malaysia

43400 UPM Serdang, Selangor Darul Ehsan

Malaysia
N.I.P. Samsudin \& N.N. Jambari

Laboratory of Food Safety and Food Integrity

Institute of Tropical Agriculture and Food Security

Universiti Putra Malaysia

43400 UPM Serdang, Selangor Darul Ehsan

Malaysia

*Corresponding author; email: norkhaizura@upm.edu.my

Received: 22 April 2020

Accepted: 18 February 2021 